\title{
KEHIDUPAN DAN KARAKTERISTIK \\ PEMIKIRAN HUKUM IMAM AHMAD BIN HANBAL
}

\begin{abstract}
Nadia*
Abstract

Ahmad Ibn Hanbal, who is an expert in the fields of hadith and Islamic jurisprudence. He is known as the founder of the Hanbali mazhab. Many assume that Ibn Hanbal is not a fukaha but only a muhaddis, an expression like this is based on his interest in deepening the field of hadith and the many hadiths he has collected and the fatwa that tends to follow Imam Shafi'i who is his teacher, which is a strong reason for the assumption. make it interesting to review what life really is like and the characteristics of his legal thought. Ahmad Ibn Hanbal is not someone who is fanatical about his fatwas and he has a method of istimbath that is different from other Imams by giving more portions to nash than ra'yu.
\end{abstract}

Keyword: Ahmad Ibn Hanbal, fikih, muhaddis, mazhab

\begin{abstract}
Abstrak
Imam Ahmad bin Hanbal merupakan seorang ahli dalam bidang hadis dan fikih. Beliau dikenal sebagai pendiri dari mazhab hanbali. Banyak yang berasumsi bahwa Imam Ahmad bukanlah seorang fukaha melainkan hanya seorang muhaddis, ungkapan seperti ini didasari dari ketertarikan beliau yang lebih mendalami bidang hadis dan banyaknya hadis yang beliau kumpulkan serta fatwa yang cenderung mengikuti Imam Syafi'i yang merupakan guru beliau
\end{abstract}


menjadi alasan kuat akan asumsi ini. Sehingga menarik untuk menilik kembali seperti apa sebenarnya kehidupan dan karakteristik pemikiran hukum beliau. Imam Ahmad bin Hanbal bukanlah seseorang yang fanatik akan fatwanya dan beliau memiliki metode istimbath yang berbeda dari Imam yang lain dengan memberi porsi yang lebih banyak pada Nash dari pada akal.

Kata Kunci: Ahmad bin Hanbal, ahli hadis, fikih, mazhab

\section{A. Pendahuluan}

Pada masa Rasulullah saw dalam penyelesaian masalah, umat islam dapat menanyakan secara langsung solusi kepada Rasulullah saw. Jawaban dari Rasulullah akan menjadi sumber hukum bagi umat islam setelah al-Quran. Jadi, sumber ajaran Islam yang utama adalah al-Quran dan hadis. Setelah beliau wafat, dengan didukung oleh perluasan daerah Islam sehingga masalah yang muncul akan lebih kompleks tergantung pada kondisi daerah dan juga perkembangan zaman yang melahirkan persoalan beraneka ragam menuntut adanya jawaban sehingga munculah sumber hukum baru melalui Ijtihad. Dari Ijtihad inilah cikalbakal lahirnya berbagai versi dalam memandang keumuman makna ayat al-Qur'an dan Hadis serta perbedaan dalam cara istimbath hukum yang dilakukan. Hal inilah, yang melahirkan aliran-aliran fikih.

Meskipun dalam literatur sejarah, munculnya aliran fikih pada saat masa tabi'in, namun sesungguhnya embrionya sudah ada jauh sebelumnya, namun belum terklasifikasi. Hadirnya dua aliran fikih pada masa tabi'in yaitu Madrasat al-Madinah (Madrasat al-Hadis) dan Madrasat al-Baghdad (Madrasat al-Ra'yi). Kedua aliran ini yang kemudian mempengaruhi pemikiran-pemikiran tokoh-tokoh fikih antara lain Al-Ra'yi yang melahirkan Imam Abu Hanifah yaitu pendiri Mazhab Hanafiyah, al-Hadis yang melahirkan Imam Malik bin Anas pendiri Mazhab Maliki. Murid Imam Malik dan Muhammad alSyaibani (Penerus gagasan Abu Hanifah) adalah Muhammad bin Idris al-Syafi'i Pendiri Mazhab Syafi'iyah, dan salah satu murid Imam Syafi'i adalah Imam Ahmad bin Hanbal yaitu Pendiri Mazhab 
Hanabilah. ${ }^{1}$ Keempat Imam Mazhab ini dikenal juga dengan Sunni atau Ahl al-Sunnah Wa al-Jama'ah.

Sumber hukum utama adalah al-Quran dan Hadis menjadi hujjah bagi para Imam mazhab dalam penentuan hukum tanpa perbedaan. Mereka memiliki pendapat yang berbeda dalam cara memaknai serta menghukumi suatu persoalan. Metode yang digunakanlah menjadi alasan utama sehingga terjadi penetapan hukum yang berbeda pula. Pada tulisan ini akan menguraikan tentang salah satu dari para Imam Mazhab, yakni Imam Ahmad bin Hanbal. Kehidupan beliau sebagai ahli fikih sekaligus pakar hadis pada zamannya dan karakteristik pemikiran beliau dalam penentuan hukum Islam.

\section{B. Pembahasan}

\section{Biografi Kehidupan Ahmad bin Hanbal}

Nama lengkap beliau adalah Abu Abdullah Ahmad bin Muhammad bin Hanbal bin Hilal bin Asad bin Idris bin Abdullah bin Hayyain bin Abdullah bin Anas bin Auf bin Qasit bin Asy-Syaibani. Keturunan Ahmad bin Hanbal bertemu dengan keturunan Rasulullah saw. Mazin bin Mu'ad bin Adnan. ${ }^{2}$ Imam Ahmad lahir sewaktu ayahnya pergi ke Marwa sebagai seorang ghazi, dan tinggal sementara disana. ${ }^{3}$ Riwayat lain mengatakan Orang tua beliau pindah dari kota Marwa, tempat tinggal sang ayah, ke kota Baghdad. Di kota Baghdad Imam Ahmad lahir. ${ }^{4}$ Terlepas dari perbedaan riwayat tempat

${ }^{1}$ Atang Abd Hakim dan Jaih Mubarok, Metodologi Studi Islam, edisi revisi, (Bandung: Remaja Rosdakarya, 2012), h. 159-160

${ }^{2}$ Ahmad Asy-Syurbasi, Sejarah dan Biografi Empat Imam Mazhab, (Jakarta: Bumi Aksara, 1993) h. 191

${ }^{3}$ Ibid., h. 146

${ }^{4}$ Ahmad Asy-Syurbasi, Sejarah dan Biografi Empat Imam Mazhab, (Jakarta: Bumi Aksara, 1993) h. 191 
kelahiran, seluruh Riwayat sepakat bulan lahir beliau tepat pada bulan Rabiul Awal tahun $164 \mathrm{H}^{5}$ (780 M). Ayahnya adalah seorang pejuang yang handal di Basrah, Muhammad bin Hanbal Sedangkan kakeknya Hanbal bin Hilal merupakan gubernur di daerah Sarkhas pada masa pemerintahan umayah. Ayah Imam Ahmad meninggal pada usia 30 tahun. Setelah ayahnya wafat, Imam Ahmad dibawa ke baghdad oleh ibunya, Shafiyah binti Maimunah binti Malik asy-Syaibani dan menetap disana. Ayah dan Ibunya adalah Suku Syaiban yang terdapat di kota Basrah karena itulah, Ahmad dijuluki Basri. Selepas Ayahnya meninggal, Ibunya lah yang mengasuhnya dengan bertani di tanah kecil yang diwariskan oleh ayah Imam Ahmad. karena rasa sayangnya pada Ibunya, Beliau baru menikah pada usia 30 tahun. $^{6}$

Hidup sebagai seorang yang pekerja keras, Imam Ahmad dari kecil sudah bekerja untuk mencari kebutuhan hidup. Kadangkala mengumpulkan sisa hasil panen atas seizin pemilik, beliau juga bekerja menulis, menenun kain atau menjualnya. Padahal beliau memiliki warisan sebuah bangunan dari ayahnya yang jika disewakan mendapatkan harga yang lumayan, namun Imam Ahmad mengingat Hadis nabi yang mengatakan makanan yang terbaik dari seorang muslim ialah yang berasal dari hasil kerjanya sendiri. Karena itulah Imam Ahmad bertekad tidak mau makan selain dari hasil kerjanya sendiri. Beliau sangat ketat dengan perkara halal, menghindari yang subhat dan tidak menerima hadiah atau pemberian. ${ }^{7}$ Sejak kecil beliau merupakan anak yang sangat rajin belajar dan memiliki minat yang tinggi terhadap ilmu pengetahuan.

Pada masa imam Ahmad, Baghdad merupakan kota yang maju serta sebagai pusat ilmu pengetahuan, tempat tinggalnya para

${ }^{5}$ Rahman I Doi, Penjelasan Lengkap Hukum-Hukum Allah: Syariah, (Jakarta: PT. RadjaGrafindo Persada, 2002), h. 145

${ }^{6}$ Abdurrahman Asy-Syarqawi, Riwayat Sembilan Imam Fiqih, (Bandung: Pustaka Hidayah, 2000), h. 458

${ }^{7}$ Ahmad Asy-Syurbasi, Sejarah dan Biografi Empat Imam Mazhab, (Jakarta: Bumi Aksara, 1993) h. 192 
terpelajar hingga beliau mulai memperdalam ilmu pengetahuan dengan mempelajari bahasa Arab, hafalan al-Quran, Hadis, serta sejarah pendahulu. Selama hidupnya, Ahmad bin Hanbal terkenal wara', pendiam, pemaaf, kuat ingatannya, peka terhadap kondisi sosial, dan juga suka bertukar pendapat. Beliau mempunyai pikiran yang cemerlang, wawasan yang luas dan kepribadian yang baik. Imam Ahmad tidak memberikan fatwa setelah ditanya, beliau tidak ingin menduga-duga atau berkhayal dalam permasalahan yang belum terjadi.

Imam Ahmad mendapatkan cobaan pada akhir masa hidupnya dengan pendirian kuat beliau menentang akan doktrin mu'tazilah tentang kemakhlukan al-Quran yang dipaksakan di masa kekuasaan al-Ma'mun, al-Mu'tashim, dan al-Watsiq. ${ }^{8}$ Kurang lebih 14 tahun beliau melewati deraan dirantai, dikurung didalam penjara kemudian dicambuk dan diinjak-injak bahkan hingga diasingkan. Beliau melaluinya dengan tabah dan setelah cobaan yang silih berganti yang beliau telah lalui, Imam Ahmad tetap melanjutkan kembali halaqahnya.

Ahmad bin Hanbal menghembuskan nafas terakhir beliau di kota Baghdad bertepatan pada hari Jumat 12 Rabiul Awwal tahun 241 $\mathrm{H}$ atau $855 \mathrm{M}$ ketika memasuki usia 77 tahun. Beberapa ulama mengatakan saat meninggal, jenazah beliau diantarkan oleh hampir 800.000 orang laki-laki dan 60.000 orang perempuan dan dimakamkan di pemakaman al-Harb. ${ }^{9}$

\section{Jaringan Intelektual}

Imam Ahmad menghafal al-Quran dan kandungannya pada umur 14 tahun. ${ }^{10}$ Pada tahun $179 \mathrm{H}$ ketika masih berusia 15 tahun beliau mulai tertarik untuk memperdalam pengetahuan sunnah dan

${ }^{8}$ Rahman I Doi, Penjelasan Lengkap Hukum-Hukum Allah: Syariah, (Jakarta: PT. RadjaGrafindo Persada, 2002), h. 148

${ }^{9}$ Ibid., h. 256-257

${ }^{10}$ Ibid., h. 193 
hadis. ${ }^{11}$ Ahmad Bin Hanbal merupakan salah seorang tokoh terkemuka dalam sejarah Islam yang menguasai ilmu hadis sekaligus hukum. Awal mula beliau mempelajari hadis dan ilmu fikih pada Abu Yusuf Yakub bin Ibrahim yakni salah satu murid dari Abu Hanifah yang merupakan aliran ra'yu. ada riwayat juga mengatakan guru pertamanya adalah Husyaim bin Basyir bin Abi Khasim al-Wasiti seorang imam Hadis di Baghdad. ${ }^{12}$ Imam Ahmad menulis lebih dari tiga ribu Hadis dari beliau. Ulama lainnya yang pernah beliau berguru padanya dibaghdad adalah Umair bin Abdullah, Abdurrahman bin Mahdi dan Abu Bakr bin 'Ayyasy.

Saat masa muda Imam Ahmad berguru Abdullah bin alMuabarak, ulama fikih yang memiliki pengetahuan yang luas dan sekaligus seorang hartawan. Ulama fikih ini, merupakan ulama yang sangat dihormati dan dikagumi oleh Imam Ahmad pribadinya, fikihnya, ilmunya, dan perilakunya terhadap sesama manusia. yang disebutkan dalam buku Riwayat 9 Imam Fikih ${ }^{13}$, guru Imam Ahmad inilah yang mengajarkan pada beliau lebih menyukai hidup miskin bukanlah seruan mengajak orang hidup zuhud, itu hanya seruan kepada orang kaya untuk lebih banyak menimbun harta. Hidup zuhud itu menerapkan sunnah Rasulullah saw. Dalam kehidupan sehari-hari, bukan menjauhkan diri dari apa yang dihalalkan Allah dan tidak mengiginkan apa saja yang tidak disukai oleh-Nya.

Pada umur 18 tahun beliau memutuskan ke luar dari Baghdad untuk mencari dan mengumpulkan sendiri hadis Rasulullah saw. Karna kecintaannya terhadap Hadis nabi tidak jarang beliau bahkan pergi kesuatu Negara atau kota yang didengarnya ada seorang ahli tentang riwayat dan Hadis Nabi, tanpa menghiraukan kelelahan dan

${ }^{11}$ M. Ali Hasan, Perbandingan Mazhab, (Jakarta: PT. RadjaGrafindo Persada, 2002), h. 222

${ }^{12}$ Ahmad Asy-Syurbasi, Sejarah dan Biografi Empat Imam Mazhab, (Jakarta: Bumi Aksara, 1993) h. 195

${ }^{13}$ Abdurrahman Asy-Syarqawi, Riwayat Sembilan Imam Fiqih, (Bandung: Pustaka Hidayah, 2000), h. 454-455 
kesulitan yang akan ditempuhnya. Beliau memulai perjalanan panjang untuk mempelajari hadis dari kota satu ke kota lainnya. Pengembaraannya yang pertama ialah Kufah, yaitu pada tahun $183 \mathrm{H}$. Kemudian ke Basrah pada tahun $186 \mathrm{H}^{14}$, Kemudian pada tahun 187 $\mathrm{H}$ beliau belajar kepada Sufyan bin 'Uyainah di Qullah beliau juga ingin belajar pada imam Malik, namun tidak kesampaian sehingga beliau pernah berkata "Malik meninggal tetapi Allah mengganti Sufyan bin Uyainah untukku"15. sekaligus menunaikan ibadah haji yang pertama kali.

Saat beliau ke Hijaz untuk menuntut ilmu, beliau bertemu pertama kali dengan Imam Syafi'i yang sedang mengajar di masjid alHaram. serta mengikuti halaqah guna mempelajari ilmu fikih dari Imam Syafi'i. Bahkan Imam Ahmad pernah berkata pada temannya yang ikut ke hijaz "Jika sampai kita terlewat memperoleh ilmu dari orang itu (Imam Syafi'i), hingga tiba hari akhir pun tidak akan menemukan penggantinya." Riwayat ini menjadi salah satu bukti kelirunya orang-orang yang mengatakan bahwa beliau bukanlah faqih melainkan hanya seorang muhaddis. Karena Imam Ahmad bukan hanya menimba ilmu hadis namun juga memiliki perhatian besar pada ilmu fikih. Imam Syafi'i pernah berkata setelah mengunjungi Baghdad "Saya keluar dari Baghdad, tidak saya tinggalkan disana seseorang yang lebih takwa, lebih wara', dan lebih alim selain Ahmad bin Hanbal yang sungguh banyak menghafal Hadis." Bahkan Imam Syafi'i juga biasa merujuk kepada Imam Ahmad kapan saja mengalami kesulitan dalam hal Hadis. ${ }^{16}$

Salah satu riwayat yang menegaskan tentang perhatian besar Imam Ahmad pada masalah-masalah fikih adalah yang ditulis dalam kitab Syaikh Manna al-Qaththan, beliau mengatakan bahwa awal mula

${ }^{14}$ Ahmad Asy-Syurbasi, Sejarah dan Biografi Empat Imam Mazhab, (Jakarta: Bumi Aksara, 1993) h.194

${ }^{15}$ Ibid., h. 196

${ }^{16}$ Rahman I Doi, Penjelasan Lengkap Hukum-Hukum Allah: Syariah, (Jakarta: PT. RadjaGrafindo Persada, 2002), h. 147 
Imam Ahmad mengambil jalan ilmu dari pakar fikih berdasarkan mazhab Ahlu Ra'yi melalui guru beliau yakni Abu Yusuf yang merupakan murid dari Imam Abu Hanifah seperti yang telah penulis jelaskan sebelumnya. Namun setelah itu beliau berpindah cenderung pada jalan para pakar hadis, oleh karenanya beliau lebih terfokus mempelajari hadis setelahnya, tapi tidak berhenti secara total dalam mempelajari fikih. ${ }^{17}$

Masih banyak lagi Guru-guru beliau yang tidak bisa disebutkan satu persatu karna banyaknya, Al-Imam Adz Dzahabi menyebutkan dalam kitab As-Siyar, jumlah guru-guru Al-Imam Ahmad yang beliau riwayatkan dalam Musnadnya lebih dari 280 orang. ${ }^{18}$

Imam Ahmad terkenal dengan kuat daya ingatnya dalam menghafal hadis, meskipun demikian, beliau tetap memiliki catatan yang menjadi rujukan utama beliau. Dalam mengajarkan dan menerangkan hadis, bisa saja beliau menggunakan hafalannya. Namun, hal ini tidak berlaku bagi para muridnya, sebab beliau tidak memperbolehkan muridnya menulis apa yang Ia sampaikan sebelum memastikan dari catatan beliau. Hal tersebut dilakukan untuk menjaga kebenaran dan keotentikan hadis yang beliau ajarkan dan terangkan. Karena menurutnya umat Islam membutuhkan spesialisasi dibidang hadis yang mempelajari, meneliti dan mengkaji ilmu hadis. ${ }^{19}$ Oleh karena itu, beliau tidak pernah memperdulikan rasa lelah demi mencapai tujuannya. Bahkan badan beliau semakin kurus, sehingga ada seorang sahabatnya mengingatkan "Kadang ke Kufah, kadang ke Basrah, kadang ke Hijaz, dan kadang ke Yaman. Sampai kapan?"

${ }^{17}$ Manna Khalil Al-Qaththan, Tarikh tasyri: Sejarah Legislasi Hukum Islam, diterj Habibussalam, (Jakarta: Ummul Qura, 2017) h. 571

${ }^{18}$ Admin, Al Imam Ahmad bin Hanbal: Tauladan dalam Semangat dan Kesabaran, (laf.or.id), 28 November 2015

${ }^{19}$ Abdurrahman Asy-Syarqawi, Riwayat Sembilan Imam Fiqih, (Bandung: Pustaka Hidayah, 2000), h. 456 
Imam Ahmad menjawab "Bersama mihbarah (wadah tinta) sampai ke maqbarah (liang kubur)" 20

Ketika berusia 40 tahun Imam Ahmad barulah bersedia membuat halaqah di masjid al-Jamii di Baghdad, ada beberapa pendapat yang mungkin menjadi salah satu alasan beliau yakni karna beliau merasa segan dengan guru-gurunya yang masih hidup yang lebih memiliki banyak pengetahuan dari dirinya. ${ }^{21}$ Serta alasan lainnya barangkali beliau merasa umur tersebut merupakan umur yang telah matang dan dewasa yakni seusia dengan Rasulullah saw. saat diutus Allah swt. Menyampaikan dakwah. ${ }^{22}$

Kehebatannya sebagai seorang muhaddis dan pakar fikih menarik perhatian orang ramai dan mereka mula mengerumuninya untuk belajar bersama di Masjid Agung Baghdad. Antara anak muridnya yang kemudian berjaya menjadi tokoh hadis terkenal ialah al-Bukhari, Muslim dan Abu Daud. ${ }^{23}$ Sedangkan murid lainnya antara lain Yahya bin Adam, Yazid bin Harun, Abu Zura'ah, Shalih bin Ahmad bin Hanbal (anak Ahmad bin Hanbal), Abdullah bin Ahmad bin Hanbal (anak Ahmad bin Hanbal), 'Abdul Malik bin Abdul Hamid bin Mahran al-Maimanui (salah seorang sahabat Ahmad bin Hanbal), Ahmad bin Muhammad bin al-Hajaj atau lebih dikenal dengan Abu Bakar al-Marwazi ${ }^{24}$

\section{Karya-Karyanya}

${ }^{20}$ Ibid., h. 456

${ }^{21}$ Ahmad Asy-Syurbasi, Sejarah dan Biografi Empat Imam Mazhab, (Jakarta: Bumi Aksara, 1993) h. 200

${ }^{22}$ Manna Khalil Al-Qaththan, Tarikh tasyri: Sejarah Legislasi Hukum Islam, diterj Habibussalam, (Jakarta: Ummul Qura, 2017) h. 573

${ }^{23}$ Sulaiman Rasjid, Fiqh Islam, cet 48, (Bandung: Sinar Baru Algensindo, 2010) h. 11

${ }^{24}$ Ahmad Asy-Syurbasi, Sejarah dan Biografi Empat Imam Mazhab, (Jakarta: Bumi Aksara, 1993) h. 206-207 
Beliau mengumpulkan kitabnya yang terkenal, al-Musnad, dalam jangka waktu sekitar 60 tahun dan itu sudah dimulainya sejak tahun $180 \mathrm{H}$ saat pertama kali beliau mencari hadis. Beliau menghimpun sejumlah empat puluh ribu hadis dalam kitab Musnadnya. ${ }^{25}$ Pada saat beliau merasa akan umurnya, beliau memutuskan untuk Menyusun kembali tulisan-tulisan yang awalnya masih terpisah dalam lembaran-lembaran, kemudian beliau mendiktekan satu persatu pada anaknya meskipun belum tersusun rapi dengan harapan anaknya lah yang akan membukukannya kelak. Kitab al-Musnad kemudian dibukukan oleh Abdullah bin Ahmad. ${ }^{26}$ Abdullah menertibkan letak al-Musnad yakni dengan mengelompokan berdasar pada periwayatan masing-masing sahabat. ${ }^{27}$

Pendapat atas masalah fikih serta hadis yang berhasil dikumpulkan oleh Imam Ahmad pada dasarnya tidak pernah dibukukan oleh beliau sendiri melainkan disusun oleh anaknya 'Abdullah, ataupun murid-murid beliau yang seterusnya disiarkan kepada seluruh umat. Berkaitan dengan karya al-Musnad masih terdapat perbedaan pendapat ulama berkaitan sejauh mana kesahihan hadis yang berada didalamnya. Ibnu Taimiyah juga menegaskan bahwa tidak semua yang diriwayatkan oleh imam Ahmad menjadi hujjah baginya, tetapi beliau meriwayatkan apa saja yang juga diriwayatkan oleh para ulama lainnya. Meskipun Beliau menghindari perawi yang dikenali sebagai pendusta, namun dalam kitabnya masih terdapat riwayat yang lemah, namun telah dijelaskan secara jelas dalam kitab oleh Abdullah. ${ }^{28}$ Sebagian ulama lainnya mengatakan

${ }^{25}$ Hudhori Bik, Terjamah Tarikh Tasyrik: Sejarah Pembentukan Hukum Islam, (Semarang: Daarul Ihya, 1980), h. 444

${ }^{26}$ Abdurrahman Asy-Syarqawi, Riwayat Sembilan Imam Fiqih, (Bandung: Pustaka Hidayah, 2000), h. 479

${ }^{27}$ Manna Khalil Al-Qaththan, Tarikh tasyri: Sejarah Legislasi Hukum Islam, diterj Habibussalam, (Jakarta: Ummul Qura, 2017) h. 576

${ }^{28}$ Ibid., 576-577 
semua Hadis dalam al-Musnad adalah sahih. Padahal Imam Ahmad telah mengatakan sendiri bahwa tidak semua hadis yang dalam Musnad nya itu di nilai olehnya sebagai hadis sahih. ${ }^{29}$

Salah satu di antara mereka adalah anaknya Shalih bin Ahmad bin Hanbal, Beliau menyebarkan madzhab ayahnya. Kemudian Abu Bakar al- Marwadzi murid Imam Ahmad yang meriwayatkan kitab alWara dari beliau, yang kemudian muridnya Abu Bakar al-Mawadzi, yang mendampinginya yakni Abu Bakar al-Khallal hingga tersusun fikih Imam Ahmad kedalam karya terbesar yang memuat Mazhab Hanbali adalah kitab al-Jami' al-Kabir. ${ }^{30}$

\section{Pemikiran Hukum Islam}

Dalam persoalan fikih, pemikiran beliau cenderung dipengaruhi oleh ijtihad Imam Syafi'i. ${ }^{31}$ Imam Ahmad bin Hanbal pernah berkata "Jika saya ditanya mengenai masalah yang saya tidak mengetahui hadisnya, saya akan menjawab menurut pendapat Syafi'i"' ${ }^{32}$ Karena inilah beberapa ulama mengatakan bahwa Imam Ahmad bukanlah seorang fukaha, melainkan seorang muhaddis. AtThabari mengatakan kalau Imam Hanbali bukan seorang Ahli Fikih tapi hanya seorang perawi Hadis dan Muqallid (orang yang bertaqlid). ${ }^{33}$

Meskipun hasil ijtihadnya cenderung dipengaruhi oleh Imam Syafi'I, bukan berarti seluruh pendapatnya sama dengan pendapat

${ }^{29}$ Abdurrahman Asy-Syarqawi, Riwayat Sembilan Imam Fiqih, (Bandung: Pustaka Hidayah, 2000), h. 479

${ }^{30}$ Manna Khalil Al-Qaththan, Tarikh tasyri: Sejarah Legislasi Hukum Islam, diterj Habibussalam, (Jakarta: Ummul Qura, 2017) h. 588

${ }^{31}$ Siah Khosyi'ah, Fiqh Muamalah Perbandingan, (Bandung: Pustaka Setia, 2014), h. 36

${ }^{32}$ Abdurrahman Asy-Syarqawi, Riwayat Sembilan Imam Fiqih, (Bandung: Pustaka Hidayah, 2000), h. 471

${ }^{33}$ Ibid., h. 442 
Imam Syafi'I. Terletak perbedaan dalam menentukan hasil akhir dari persoalan fikih beliau. Ciri khas keunggulan dari fatwa Imam Ahmad ialah berdiri di atas dasar fikih hadis. ${ }^{34}$ Imam Ahmad bin Hanbal dalam menentukan persoalan hukum menggunakan asas sebagai berikut: ${ }^{35}$

a. Asas pertama yang dipergunakan oleh Imam Ahmad dengan merujuk pada Nash al-Qur'an dan hadis. Jika beliau menemukan jawabannya pada nash, maka beliau akan mengesampingkan dasar hukum lainnya seperti amalan, pendapat, ataupun Qiyas yang menyelisihnya.

b. Asas kedua Fatwa para sahabat. Apabila dalam al-Qur'an dan Hadis tidak beliau dapatkan jawaban atas persoalan yang terjadi, maka beliau memilih fatwa dari sahabat. Pendapat sahabat yang tidak memiliki perbedaan, ataupun tidak satupun sahabat yang menyelisih pendapat tersebut dapat dijadikan hujjah setelah Nash al-Quran dan Hadis menurut Imam Ahmad. Namun Imam Ahmad tidak menyebut ini sebagai Ijma. ${ }^{36}$

c. Asas ketiga yakni memilih salah satu pendapat sahabat yang diperselisihkan. Jika dalam Nash dan Fatwa Sahabat yang disepekati tidak terdapat jawaban maka Imam Ahmad memilih fatwa sahabat yang diperselisihkan. Beliau akan memilih salah satu dari pendapat tersebut untuk dijadikan hujjah. Tentu saja Imam Ahmad memilih pendapat yang menurut beliau paling sesuai dengan kandungan Nash al-Quran dan Hadis.

d. Asas keempat yakni memakai hadis mursal serta hadis dha'if dalam penentuan hukum setelah fatwa sahabat. Hadis mursal bisa dijadikan sebagai pegangan jika memang tidak terdapat jawaban

${ }^{34}$ Manna Khalil Al-Qaththan, Tarikh tasyri: Sejarah Legislasi Hukum Islam, diterj Habibussalam, (Jakarta: Ummul Qura, 2017) h. 578

${ }^{35}$ Sulaiman Rasjid, Fiqh Islam, cet 48, (Bandung: Sinar Baru Algensindo, 2010) h. 11

${ }^{36}$ Marzuki, Ahmad bin Hanbal: Pemikiran Fiqih dan Ushul Fiqihnya, (Jurnal Hunafa Vol. 2 No. 2 Agustus 2005) h. 112 
atas suatu masalah dalam asas sebelumnya menurut Imam Ahmad. Beliau menolak hadis dengan perawi yang dikenal dengan pendusta namun tidak menolak hadis yang perawinya belum sampai kedalam kategori tsiqah. ${ }^{37}$ Kategori hadis yang termasuk dha'if dalam perspektif beliau jika dikategorikan pada pengelompokan hadis maka masuk kedalam hadis Hasan. ${ }^{38}$ Beliau lebih memilih untuk menggunakan hadis berderajat dhaif, tapi bukan termasuk hadis maudu menurut beliau daripada menolaknya dan memilih mendahulukan akal.

e. Asas kelima yang beliau gunakan adalah Qiyas. Setelah tidak didapatkan jawaban dari masalah hukum dengan menggunakan keempat asas sebelumnya maka jalan terakhir yang beliau tempuh yakni dengan qiyas. Dalam metode qiyas yang dilakukan Imam Ahmad bukan hanya melihat pada illat (sebab) seperti yang ditempuh imam fikih. tapi beliau menggunakan perspektif lain yakni dengan juga melihat hikmah yang tercakup dalam hukum itu sendiri. Sebab illat adalah sebabnya, sedangkan hikmah adalah tujuannya. ${ }^{39}$

Dikatakan dalam buku Sejarah dan Biografi Empat Mazhab Ahmad bin Hanbal terkadang mengambil Qiyas dan Ijma' jika ada, juga mengambil al-mashalihul mursalah, dan Sadduz Zara'i yaitu apabila tidak ada nas yang mengatakan halal atau haram bagi sesuatu maka perkara itu tetap dengan halalnya ${ }^{40}$. Sedangkan menurut Abu Zahra Istishan, dan Istishab ${ }^{41}$ juga dipakai oleh Imam Ahmad. Ahmad

${ }^{37}$ Abdurrahman Asy-Syarqawi, Riwayat Sembilan Imam Fiqih, (Bandung: Pustaka Hidayah, 2000), h. 489

${ }^{38} \mathrm{Ibid}$, h. 494

${ }^{39}$ Ibid, h. 490

${ }^{40}$ Ahmad Asy-Syurbasi, Sejarah dan Biografi Empat Imam Mazhab, (Jakarta: Bumi Aksara, 1993)

${ }^{41}$ Marzuki, Ahmad bin Hanbal: Pemikiran Fiqih dan Ushul Fiqihnya, (Jurnal Hunafa Vol. 2 No. 2 Agustus 2005) 
bin Hanbal menempuh jalan qiyas dengan arti seluas-luasnya, sehingga mencakup unsur kemaslahatan (mashalihul mursalah), Sadduz Zara'i, Istishab, kemudian memfatwakan hukum atas dasar Istihsan. ${ }^{42}$

Berkaitan dengan ijma', Imam Ahmad mengatakan ijma' para sahabat dapat menjadi sumber hukum disebabkan ketidak mungkinan para sahabat mengingkari sunnah dan al-Quran karena merekalah para perawi. Namun Imam Ahmad tidak mengakui keberadaan ijma' setelah periode sahabat. Karena tidak mungkin terjadi kesepakatan dengan luasnya jangkauan daerah Islam.

Perkembangan pemikiran Ahmad bin Hanbal ini memang tidak begitu luas mungkin disebabkan karena tempat lahirnya mazhab ini di daerah yang notabene tersohor dengan pemikiran aliran ra'yi, namun Imam Ahmad hadir dengan pemikiran aliran hadis. ${ }^{43}$ Bukan hanya itu saja, sebab lainnya yakni larangan mencatat fatwa beliau. Imam Ahmad sering melarang menulis fikih yang diajarkannya, Beliau khawatir bila fikih dibukukan, maka akan membuat hukum menjadi beku, dan akan menimbulkan taklid buta yang merajalela sepanjang masa. Sedang fikih pasti mengalami pembaharuan sesuai dengan tuntutan zaman. ${ }^{44}$ Imam Ahmad dalam menjawab atau memberikan fatwa tidak akan terburu-buru menjawabnya sebelum menyelidikinya, beliau bukan seorang yang fanatik akan pendapatnya. karena seringnya berubah pandangan. Beliau tidak segan-segan untuk mengganti pendapatnya jika seandainya ada yang lebih benar darinya. Riwayat dari Abu Daud bahwa Ahmad bin Hanbal suatu hari berkata padanya: "Jangan engkau bertaqlid padaku, pada Malik, pada Syafi'i,

${ }^{42}$ Abdurrahman Asy-Syarqawi, Riwayat Sembilan Imam Fiqih, (Bandung: Pustaka Hidayah, 2000), h. 494

${ }^{43}$ Ibid.

${ }^{44}$ Ibid, h. $481-482$ 
serta janganlah pada Tsaury. melainkan ambillah dari sumber kami mengambil. $" 45$

Imam Ahmad memiliki prinsip kuat melarang fatwanya untuk dicatat beliau pernah mengatakan kepada muridnya "Janganlah kamu menulis pendapat dariku. Karena bisa saja esok pendapatku berubah"46 oleh karenanya kitab-kitab yang bermunculan yang memuat pemikiran fikih dari Imam Ahmad sesungguhnya bukanlah hasil pembukuan oleh beliau melainkan dari hasil catatan oleh murid-muridnya dan kemudian disusun dan dibukukan. Hasil dari kegiatan para murid dan pengikutnya lah yang menjadikan mazhab hanbali perlahan-lahan tersebar kedaerah-daerah lain hingga sekarang memiliki pengikut yang banyak tersebar di seluruh jazirah Arab, Palestina, Syria, dan Irak. Serta dijadikan sebagai mazhab resmi pada pemerintahan Saudi Arabia. $^{47}$

Mazhab Hanabilah dikenal dengan mazhab yang memiliki kecenderungan memahami Nash secara tekstual dengan sikap kaku dan kerasnya, para pengikut yang menyebarkan mazhab ini bertindak ekstrem, sehingga pada akhirnya banyak orang kemudian berpandangan sempit akibat perbuatan mereka kata Hanbali atau Hanabilah disamakan dengan kebodohan, kaku membatu, dan fanatik buta. ${ }^{48}$ Padahal pada masa Ahmad bin Hanbal beliau tidak pernah mengajarkan pada muridnya untuk bertindak kasar, karna beliau berpegang pada Sunnah dan al Quran.

${ }^{45}$ M. Ali Hasan, Perbandingan Mazhab, (Jakarta: PT. RadjaGrafindo Persada, 2002), h.228

${ }^{46}$ Marzuki, Ahmad bin Hanbal: Pemikiran Fiqih dan Ushul Fiqihnya, (Jurnal Hunafa Vol. 2 No. 2 Agustus 2005) h. 110

${ }^{47}$ Sulaiman Rasjid, Fiqh Islam, cet 48, (Bandung: Sinar Baru Algensindo, 2010) h. 11

${ }^{48}$ Abdurrahman Asy-Syarqawi, Riwayat Sembilan Imam Fiqih, (Bandung: Pustaka Hidayah, 2000), h. 447 
'Serulah (manusia) kepada jalan Tuhan-mu dengan hikmah dan pelajaran yang baik dan bantahlah mereka dengan cara yang baik. Sesungguhnya Tuhanmu Dialah yang lebih mengetahui tentang siapa yang tersesat dari jalan-Nya dan Dialah yang lebih mengetahui orang-orang yang mendapat petunjuk.' (Q.S. An-Nahl [16]: 125)

Sikap fanatisme mazhab dan terkesan kaku mungkin disebabkan oleh karakteristik dari metode hukum yang digunakan Imam Ahmad yang memberikan porsi sangat kecil pada penggunaan akal dan lebih mendahulukan nash serta perkataan sahabat. Penulis kemudian merasa sikap keras yang ditampilkan mazhab ini bukanlah pure dari benih pemikiran Imam Ahmad namun dari banyaknya pemikiran-pemikiran yang kemudian hadir dan dipraktikan dari para pengikut mazhab ini. Jika memang sosok Imam Ahmad yang melarang dan keras untuk seluruh amalan yang tidak memiliki dasar dari Nash, tentu saja beliau tidak akan pernah mengeluarkan fatwa yang terkadang tidak berdasarkan Nash. ${ }^{49}$ Bahkan catatan menarik tentang jalan fikih beliau adalah kecintaan beliau kepada Imam Syafi' $i$ seperti yang telah penulis jelaskan sebelumnya, Beliau bahkan pernah berkata yang dikutip oleh Imam al-Baihaqy dan kemudian dikutip kembali oleh Ardiansyah dalam jurnalnya yakni

"Ahmad bin Hanbal berkata: dalam setiap shalatku selama 40 tahun, aku selalu mendoakan Imam Syafi'i. Memohon ampunan aku dan kedua orangtuaku serta Muhammad bin Idris Syafi'i. Tidak ada seseorang lainnya yang sangat mengikuti hadis Rasulullah saw melebihi dirinya."

Jadi, sesungguhnya perbuatan Imam Ahmad yang memutuskan suatu fatwa tanpa ada landasan Nashnya menjadi bukti bahwa kecenderungan Imam Ahmad yang mengikuti pemikiran Imam Syafi'i yang membagi hal yang baru menjadi dua yakni yang baik dan yang buruk. Sehingga tidak menyama ratakan bahkan melarang

${ }^{49}$ Ardiansyah, Pengaruh Mazhab Hanbali dan Pemikiran Ibnu Taimiyah Dalam Paham Salafi, (Jurnal Analytica Islamica, Vol. 2, No. 2, Tahun 2013) h. 252-254 
dengan keras semua hal yang baru yang belum pernah dibahas dalam Nash.

Karakteristik pemikiran Imam Ahmad bin Hanbal lebih memberikan porsi sangat besar pada Nash dan perkataan sahabat sehingga penggunaan akal pada hasil pemikiran beliau mendapatkan porsi yang sangat kecil namun bukan berarti tidak sama sekali. Beliau menetapkan Qiyas pada salah satu dari kelima asas hukum yang sesuai hirarkinya berada diakhir. Syekh Abu Zuhrah berkata bahwa Imam Ahmad bin Hanbal bukanlah termasuk orang yang menolak qiyas, akan tetapi beliau termasuk dari orang yang berpegang padanya. ${ }^{50}$

\section{Kesimpulan}

Nama lengkap beliau adalah Abu Abdullah Ahmad bin Muhammad bin Hanbal bin Hilal bin Asad bin Idris bin Abdullah bin Hayyain bin Abdullah bin Anas bin Auf bin Qasit bin Asy-Syaibani. Beliau dikenal sebagai Ahmad bin Hanbal. Beliau adalah seorang ulama yang teguh pendiriannya di jalan Islam. Bahkan pada zamanya sedang merajalelanya bid'ah dan merusak akan pemahaman al-Quran sehingga beliau merasa perlunya kembali berpegang pada al-Quran dan Sunnah. Oleh karenanya beliau awalnya menuntut ilmu pada bidang fikih, namun karena ketertarikan beliau lebih besar pada hadis sehingga beliau lebih terfokus pada pencarian hadis selama masa hidupnya.

Kecintaannya kepada belajar hadis, bukan berarti beliau meninggalkan bidang fikih. Beliau juga belajar fikih dari guru-guru beraliran ra'yu, dan hadis sehingga Julukan yang disematkan kepada Imam Ahmad sebagai muhaddis tidak kalah dengan julukan beliau sebagai fukaha. Imam Ahmad bin Hanbal merupakan ahli fikih sekaligus pakar Hadis di zamannya, dalam Hadis beliau telah melahirkan kitab hadis yaitu al-Musnad yang terdiri dari 40.000 Hadis

${ }^{50}$ Manna Khalil Al-Qaththan, Tarikh tasyri: Sejarah Legislasi Hukum Islam, diterj Habibussalam, (Jakarta: Ummul Qura, 2017) h. 587 
didalamnya, sedangkan dalam fikih, pemikiran beliau merupakan cikal bakal dari lahirnya Mazhab Hanbali. cara yang beliau gunakan dalam meng- istinbathkan hukum yang secara hirarki secara berurutan yakni al-Quran, Sunnah, Fatwa Sahabat dan pendapat sahabat yang bertentangan, hadis mursal dan hadis dhaif juga yang terakhir dipakai jika benar-benar tidak ada jalan lagi yaitu qiyas. Karakteristik pemikiran Ahmad bin Hanbal memberikan alokasi terbesar pada nash dan fatwa sahabat dibandingkan penggunaan akal.

\section{Referensi}

Asy-Syurbasi, Ahmad. Sejarah dan Biografi Empat Imam Mazhab, Jakarta: Bumi Aksara, 1993

Al-Qaththan, Manna Khalil. Tarikh tasyri: Sejarah Legislasi Hukum Islam, diterj Habibussalam, Jakarta: Ummul Qura, 2017

Admin, Al Imam Ahmad bin Hanbal: Tauladan dalam Semangat dan Kesabaran, (laf.or.id), 28 November 2015

Asy-Syarqawi, Abdurrahman. Riwayat Sembilan Imam Fiqih, Bandung: Pustaka Hidayah, 2000

Ardiansyah, Pengaruh Mazhab Hanbali dan Pemikiran Ibnu Taimiyah Dalam Paham Salafi, Jurnal Analytica Islamica, Vol. 2, No. 2, Tahun 2013

Bik, Hudhori. Terjamah Tarikh Tasyrik: Sejarah Pembentukan Hukum Islam, Semarang: Daarul Ihya, 1980

Doi, Rahman I. Penjelasan Lengkap Hukum-Hukum Allah: Syariah, Jakarta: PT. RadjaGrafindo Persada, 2002

Hakim, Atang Abd dan Jaih Mubarok. Metodologi Studi Islam, edisi revisi, Bandung: Remaja Rosdakarya, 2012

Hasan, M. Ali. Perbandingan Mazhab, Jakarta: PT. RadjaGrafindo Persada, 2002 
Comparativa Vol. 1 No. 2, Juli - Desember 2020

Khosyi'ah, Siah. Fiqh Muamalah Perbandingan, Bandung:

Pustaka Setia, 2014

Marzuki, Ahmad bin Hanbal: Pemikiran Fiqih dan Ushul Fiqihnya, Jurnal Hunafa Vol. 2 No. 2 Agustus 2005

Rasjid, Sulaiman. Fiqh Islam, cet 48, Bandung: Sinar Baru Algensindo, 2010 